\title{
Privacy, Poverty, and the Constitution
}

\section{Albert M. Bendich*}

We are coming to recognize that the legal assistance we have given some poor men has been only a beginning .... [W] e are coming to recognize how fundamental is the role of law in providing every man membership—and not merely existence - in our society.... The scales are now tipped against the poor . . . . The solution is not charity, but justice. ${ }^{1}$

A rticle 22 of the Untversal Declaration of Human Rigats provides that "everyone, as a member of society has the right to social security and is entitled to realization ... of the economic, social and cultural rights indispensable for his dignity and the free development of his personality."

In our own society, the constitutional guarantee of privacy has increasingly come to be thought of as protecting dignity and free development of personality. And the pattern of Supreme Court decisions has recently begun to suggest that the first, fourth, fifth, and nimth amendments are to be seen as parts of an integrated framework guaranteeing various aspects of the "privacy" or "dignity" or "freedom" of the individual. ${ }^{2}$

The "economic, social and cultural rights" which the Universal Declaration of Human Rights expressly describes as being indispensable to dignity and free development of personality are largely assumed in our society to be made available in ways that do not require their legal provision.

The war on poverty, however, has focused attention on the fact that the indispensable conditions of privacy, dignity, and freedom are lacking for millions of Americans. Thus, while the Constitution's guarantees presuppose the existence of these indispensable conditions, ${ }^{2 a}$ their actual nonexistence tends to reduce the guarantees themselves to mere suppositions.

Poverty is thus simultaneously a condition which deprives individuals of freedom and dignity and undermines the most fundamental constitutional guarantees. But, if poverty is at war with the Constitution, the Constitution is equally at war with poverty. It is the central thesis of

* A.B., 1950; M.A., 1952 ; LL.B., 1955; University of California, Berkeley. Associate Professor of Speech, University of California, Berkeley; Member, California Bar.

1 Address by Attorney General Nicholas deB. Katzenbach to the National Conference on Law and Poverty, Washington D.C., June 24, 1965, pp. 1, 4.

2 See, e.g., Griswold v. Connecticut, 381 U.S. 479, 484 (1965).

2a Thus, e.g., the fourth amendment's guarantee of freedom from unreasonable searches and seizures ("The right of the people to be secure in their persons, louses, papers and effects") presupposes, inter alia, that persons have houses. 
this paper that persons in our society have a constitutional right to privacy and to the conditions which are indispensable to its realization. By reasoning similar to that by which we have recently come to understand that the guarantee of due process requires a lawyer to be provided for persons too poor to engage private counsel, because a defense attorney is an indispensable aspect of justice in a crirninal trial, this paper works its way to conclusions requiring, as matters of constitutional entitlement, provision of the minimal necessaries of "membership-and not merely existence-in our society." For the millions of Americans who are povertystricken, this approach means invoking the whole range of fundamental rights and principles, which have hitherto been as inaccessible to them as if they had lived in some other time and place, and insisting that the Constitution be taken seriously not only for the privileged but for the underprivileged as well. The ultimate conclusion, therefore, is that the war against poverty is not a war to rescue the poor so much as it is a war to defend the constitutional principles of freedom, dignity, and equality. It is not a matter of charity, but of justice.

I

PRIVACY

\section{A. Background}

"The right to be let alone," Justice Brandeis wrote, is "the most comprehensive of rights and the right most valued by civilized men." Justice Douglas added that the "right to be let alone is indeed the beginning of all freedom." And the Supreme Court has held that "the right of privacy is a fundamental personal right, 'emanating from the totality of the constitutional scheme under which we live.' "15

We can appreciate the significance of the right to privacy in several ways; perhaps the simplest is to try to imagine what life under total official scrutiny would be like. Here we are indebted to George Orwell for his image of "Big Brother." The painful details-the spies, human and mechamcal, the suspicion, the fear, the feelings of exposure, helplessness -add up to a portrait of inhuman tyranny. It is these details and this picture against which the right to privacy is clesigned to protect us.

But the right to privacy has a positive as well as a negative function. Historically, the right to privacy is intimately tied up with the nurturing of independence of mind and spirit. It is part of the process of civilization struggling to overcome tyranny and oppression. It is related most intimately to the development of the first amendment freedoms: conscience,

3 Olmstead v. United States, 277 U.S. 438, 478 (1928) (dissenting opinion).

4 Public Util. Comm'n v. Pollak, 343 U.S. 451, 467 (1952) (dissenting opinion).

${ }^{5}$ Griswold v. Connecticut, 381 U.S. 479, 494 (1965) (Goldberg, J., concurring). 
speech, press, assembly, petition. But, basically, the right to privacy grew up as part of the ongoing struggle for the freedom and dignity of the individual, his right to determine his own destiny, to think and choose for himself, and to join in association with free and equal fellow citizens in shaping and working to reach common social and political ends.

Early in the process of these struggles, it was discovered that freedom from intrusion, security of one's person, house, papers, and effects from uninvited scrutiny, from unreasonable searches and seizures, was basic to freedom and dignity: that if the people were to be masters, they must not be treated as servants; that free men were independent men-not supphants, and not beggars; but indeed rulers and choosers.

These are some of the reasons underlying James Otis' denunciation in 1761 of the hated writs of assistance (general warrant pursuant to which the King's agents could at their pleasure conduct exploratory searches of men's homes for evidence of contraband) as "the worst instrument of arbitrary power," and as placing the "liberty of every man in the hands of every petty officer." John Adams, after he became President, said of Otis' speech: "then and there the child Independence was born."

General warrants had been a tool of the Star Chamber, under the repressive regimes of the Tudors ${ }^{7}$ and the Stuarts, ${ }^{8}$ for the searching out of dissenters and the literature of dissent. Men hike Wilkes and Lilburne were whipped and tortured because of their opmions and writings which, because they questioned or did not agree with state policy, were deemed criminal and styled "seditious libels." Out of the struggles of this period, as part of the growing understanding of the sort of procedures which were

6 TUdor, LIFE OF JAMres OTIS 61, 66 (1823), quoted by Justice Frankfurter in Frank v. Maryland, 359 U.S. 360, 364 (1959).

${ }^{7}$ A Star Chamber decree of 1586 provided "that it shall be lawful ... to make search in all workhouses, shops, warehouses of printers, booksellers, bookbinders or where they shall have reasonable cause of suspicion ...." The books thus seized were to be inspected by ecclesiastical officers who were to decide whether they should be burnt. The Tudor censorship employed these powers "to suppress both Catholic and Puritan dissenting literature." Marcus v. Search Warrant, 367 U.S. 717, 725 (1961). See also Siebert, Freedom of the Press IN ENGLAND, 1476-1776, at 83, 85-86, 97 (1952).

8 In Stanford v. Texas, 379 U.S. 476, 482 (1965), Justice Stewart, speaking for a unanimous Court, said: "But while the Fourth Amendment was most immediately the product of contemporary revulsion against a regime of writs of assistance, its roots go far deeper. Its adoption in the Constitution of this new nation reflected the culmination in England a few years earlier of a struggle against oppression which had endured for centuries. The story of that struggle has been fully chromicled in the pages of this Court's reports [see Marcus v. Search Warrant, 367 U.S. 717, 724-29 (1960); Frank v. Maryland, 359 U.S. 360, 363-66 (1958) (dissenting opimion). See also Boyd v. Umited States, 116 U.S. 616 (1885)] and it would be a needless exercise in pedantry to review again the detailed history of the use of general warrants as instruments of oppression from the time of the Tudors, through the Star Chamber, the Long Parliament, the Restoration, and beyond." See also Hasson, GoverNMENT AND THE PRESS, 1695-1763 (1936). 
necessary to protect and assist the development of freedom of speech and other aspects of political freedom, the English law developed the privilege against self-incrimination, to protect the privacy of a person's thoughts against the destructive prying of inquisitors, and the requirement of special as opposed to general warrants, safeguarding the privacy of a person's body, house, papers, and effects. ${ }^{9}$

Thus the zone of independence, dignity, and privacy was widened. These achievements symbolized the presence among the people of a certain new authority, a certain new power and freedom; it also signified a certain new limit to the authority of the state. It removed certain subjects and certain areas from the possibility of official scrutiny. To be one's own master in these categories was to be no man's slave and to preclude the attitudes of mastery and servility appropriate to slavisliness. In this realm, no man was to be beholden to any other, no man was to be dependent on another; "charity" was therefore inconsistent with the emergence of democratic concepts of the relation between the state and the individual. These were the principles which "privacy" implied, nurtured, and protected.

Later, these English achievements were partially embodied in the guarantees of the fifth and fourth amendments of our Bill of Rights. But Otis had wanted no more than to have such established rights of Englishmen as these extended to the Colonists when, in his famous speech denouncing writs" of assistance, he said: "A man is as secure in his house as a prince in his castle. This is the privilege of the House and it obtains if a man be deeply in debt or if civil process be served against him. Only for felonies may an officer break and enter-and then by special, not general warrant. For general warrants there is only the precedent of the Star Chamber . . .."10

As we know, it required a revolution before Americans could begin to enjoy some of the great rights which had been won in the preceding centuries in England. And after the revolution, a Constitution and Bill

9 "In 1765, in England, what is properly called the great case of Entick v. Carrington, 19 Howell's State Trials, col. 1029, announced the principle of English law which hecame part of the Bill of Rights and whose basic protection has become embedded in the concept of due process of law. It was there decided that English law did not allow officers of the Crown to break into a citizen's home, under cover of a general executive warrant, to search for evidence of the utterance of hbel. Among the reasons given for that decision were these: 'It is very certain that the law obligeth no man to accuse himself; because the necessary means of compelling self-accusation, falling upon the innocent as well as the guilty, would be both cruel and unjust; and it should seem, that search for evidence is disallowed upon the same principle. There too the innocent would be confounded with the guilty.' Id. at col. 1073," quoted by Justice Frankfurter in Frank v. Maryland, 359 U.S. 360, 363 (1959).

10 BoweN, John Adams aNd the AMarrican Revolution 215 (1950), quoted in Barth, THe PrTCE OF LIBerty, 71-72 (1961). 
of Rights-building upon, incorporating, and extending these great rights - had to be hammered out and ratified before the country could be said to have consolidated its drive for independence.

Of course, consolidation did not mean that the principles implicit in the revolution were fully realized. Slavery, poverty, illiteracy, racial and sexual discrimination, property qualifications ${ }^{11}$-all these and other inconsistent attitudes, conditions, and practices co-existed with the principles of justice, freedom, equality, dignity, privacy, and democracy. Such attitudes, conditions, and practices sapped the vitality of the revolutionary principles just as the latter militated against slavery and social and sexual discrimination. But the history of the struggles for freedom of the press, for freedom from unreasonable searches and seizures, for freedom from torture and inquisition, for freedom from taxation without representation, for freedom from the quartering of troops upon a peacetime civilian population, for freedom from the oppression of all arbitrary discriminationthe history of these struggles "was, of course, part of the intellectual matrix within which our constitutional fabric was shaped."12 And that history makes unmistakably clear the intimate relation and interdependence of the first, fourth, and fifth amendments to the Constitution, and displays a pattern designed for "safeguarding not only privacy and protection against self-incrimination but 'conscience and liuman dignity and freedom of expression as well." "13 From this perspective, the characterization of the right to privacy as "the most comprehensive of rights,"14 "the beginning of all freedom," "15 "the right most valued by civilized men," 10 and a "fundamental personal right emanating from the totality of the constitutional scheme under whicl we live,"17 appears entirely appropriate.

In the past decade and a half, we liave lad occasion to review this history and its meaning with particular frequency and immediacy because of the accelerated and intensified assaults upon these great principles and rights generated in part by the paranoia of the cold war years, and, in part, reflecting the growth of a corporate, managerial, bureaucratized society. With the proliferation of loyalty oaths, legislative investigating committees, security checks by public and private employers, the consequent suspicions which were created and aroused, and the potent new

11 Cf. Harper v. Virginia State Bd. of Elections, 86 Sup. Ct. 1079 (1966).

12 Marcus v. Search Warrant, 367 U.S. 717, 729 (1961).

13 Stanford v. Texas, 379 U.S. 476, 485 (1965), quoting Justice Douglas' dissenting opinion in Frank v. Maryland, 359 U.S. 360, 376 (1959).

14 Olmstead v. United States, 277 U.S. 438, 478 (1928) (dissenting opinion).

16 Public Util. Comm'n v. Pollak, 343 U.S. 451, 467 (1952) (dissenting opinion).

10 OImstead v. United States, 277 U.S. 438, 478 (1928) (dissenting opinion).

17 Poe v. Ullnaan, 367 U.S. 497, 521 (1960) (Douglas, J., dissenting). 
techniques for ferreting out information which the psychologists and the electronic engineers developed and made available, it became imperative that the various meanings of privacy and the reasons for its development as a summation of various fundamental rights of free and civilized people be reviewed, relearned, and meaningfully reasserted in the changed context of an oligopolistic and welfare as opposed to a laissez faire society. ${ }^{18}$

In this age of masses, concentration, and experts, it has become evident that the rhetorical formulas of political freedom must rest upon the substantive ground of mdividual dignity, nurtured and protected by individual rights, if our professed intention to build the great society is to be regarded seriously, not as cynical politicians' talk. Repeatedly, and in the most varied ways, recent experience has sliown that without privacy for family life, without security in the home to allow for and nourish the development of a sense of self, without a feeling of personal security (a sense of freedom from fears of injury or reprisal for thinking and speaking honestly, acting autonomously) necessary to the development of independent opinions and the courage to stand by them, there could be no such thing as a free people. Self-government, as we rediscovered, presupposes self-respecting individuals; self-respecting individuals presuppose self-managing, freely choosing, independent individuals committed to respecting the rights of others. The concept of a free society was shown to be inseparable from the dignity of its constituents. Thus, as we learned, the constitutional doctrine sunming up and symbolizing many of these values-"guaranteeing" them-is the "right to privacy."

In this regard it is important to return to the context of Justice Brandeis' statement, quoted at the beginning, about the right of privacy:

18 The old frontier was lost. Seemingly, the virtues of the Jeffersonian yeomanry, independence, autonomy - the virtues which the Bill of Rights had been framed to protect-were being lost too. Instead of a yeomanry of sturdy individuals, a lonely crowd; instead of self governing persons, other directed masses. In the face of onslaughts upon people and the values of the first, fourtb, and fifth amendments such as the investigation by legislative committees of political thoughts, associations, reading habits; the growth of conspiracy concepts matching the growth of managerial power in the few to direct and control the many; the development of "security" consciousness both politically and industrially; the drive for conformity reflected in such conditions as corporate scrutiny of the quabities of junior executives' wives, and psychological inquisitions into their souls (to which William Whyte responded with the advice: "cheat-respect yourself"l, Whyte, ORGanizition MaN 405-10 (1956))in the face of such onslaughts upon privacy it is not surprising to find Americans generally so insensitive to invasions of the right. And, of course, the poor, who have listorically been the most oppressed and deprived, have suffered the most vicious, and the least noticed, invasions of privacy. (No one advises the poor to "cheat." And in a recent best seller, PACKARD, NAKED SOCIETY 275-76 (1964), dcaling with privacy, a mere sixteen lines is devoted to the poor; and they take note of only the most superficial invasions of privacy.) Perhaps, for that reason, the vindication of their rights may redeem us all. 
"The makers of our constitution," he said,

undertook to secure conditions favorable to the pursuit of happiness. They recognized the significance of man's spiritual nature, of his feelings and of his intellect. They knew that only a part of the pain, pleasure, and satisfactions of hife are to be found in material things. They sought to protect Americans in their beliefs, their thoughts, their emotions and their sensations. They conferred as against the Government, the right to be let alone-the most comprehensive of rights and the riglit most valued by civilized men. ${ }^{19}$

\section{B. The Right To Be Let Alone}

The right to be "let alone," as a phrase, is not of course to be taken literally. It requires little reflection to perceive that persons do not construe their dignity, mdependence, or privacy as being threatened when firemen arrive to put out a blaze. Indeed, to be "let alone" in such circumstances could very well preclude dignity, independence, and privacy as efficiently as "the midnight knock on the door." In the same way, it is clear that for the government to leave persons alone in other areas of hife might be equally destructive of their independence, dignity, and privacy. For example, should the government leave persons under unlawful, violent physical attack alone, or should it go to their assistance? Is it violative of, compatible with, or a prerequisite to dignity, independence, and privacy for the government to furnish financial assistance to those who would otherwise be destitute? Obviously, it is a governmental obligation to protect citizens against violent physical attack. Is there not a similar obligation to protect citizens against destructive and violent economic change? Against the ravages of planned or at least controllable economic change? Is there not an obligation to protect persons against ignorance by providing schools? ${ }^{20}$ Can persons in our society achieve independence or dignity or privacy without some minimal income, some minimal housing, some minimal education? If it is only government action which can assure minimal economic and social security and if government by a policy of avoidance and inaction deprives persons of these necessities, does it not violate the gnarantee of due process as well as equal protection? Do these gnarantees not require the welfare state to provide welfare? Indeed, in this post laissez faire age, does not the "totahity of the constitutional

10 Olmstead v. United States, 277 U.S. 438, 478 (1928) (dissenting opinion).

20 In Brown v. Board of Educ., 347 U.S. 483, 493 (1954), a unanimous Supreme Court declared: "Today, education is perhaps the most important function of state and local governments. Compulsory school attendance laws and the great expenditures for education both demonstrate our recognition of the injportance of education to our democratic society. It is required in the performance of our most basic public responsibilities, even service in the armed forces. It is the very foundation of good citizenship." 
scheme under which we live" require the provision of at least the minimal prerequisites of meaningful membership in the society? ${ }^{21}$

\section{Privacy and Poverty}

As a matter of abstract consideration it seems clear that poverty and privacy are intimately and inversely related. If the essence of the right to privacy is in that pattern of rights making for meaningful freedom of choice in the context of our society, it requires hittle reflection to perceive that nutritional or cultural starvation constitutes a form of compulsion or constraint rather incompatible with such freedom. This is imphicit in the popular phrase "beggars can't be choosers." Indeed, the concept of a man's lome being his castle, for purposes of security and privacy, presupposes not only the existence of a house but also that the man will be able to enter, leave, and provision it in such a way that it is not his prison or dungeon. Solitary confinement though it may confer solitude, is not our concept of "the right most valued by civilized men." The concept of a "home" presupposes that its inhabitants will not be under economic seige. But, historically, the poorhouse (during the very period of the development of the concept of privacy) was a prison rather than a home; and that history is shockingly modern. ${ }^{22}$

In England, contemporaneously with the development of the concept of the security of the home, poor men were not only beseiged by the effects of such economic forces and policies as the shift from feudal to capitalist

21 Cf. Burton v. Wilmington Parking Authority, 365 U.S. 715, 725 (1961): "[N]o state may effectively abdicate its responsibilities by either ignoring them or by merely failing to discharge them .... By its inaction ... the State has not only made itself a party to the refusal of service, but has elected to place its power, property, and prestige behind the admitted discrimination."

22 "In 1824 after a public uproar and an official investigation, the state [New York] initiated a system of county poorhouses, and within a decade fifty counties had erected such institutions. Outdoor relief was virtually abolished; all poor were to be sent to the poorhouse 'unless the sickness of the pauper prevent.' All vagrants if 'proper objects for such relief' were to be sent there unless 'notorious offenders.' At the discretion of the justice of the peace with the concurrence of the superintendent, disorderly persons might also be sent there instead of to jail. The justice's warrant need only state 'generally, that such person has been convicted of being a disorderly person without more particular specification of the offense.' Children under fifteen found begging were also to be sent to the poorhouse until able to support themselves. Vagrants and disorderly persons were to be kept at hard labor, and all other inmates were to labor to the extent of their ability. The superintendents of the poorhouses, with the consent of a majority of the judges of the county court, were empowered to establish 'such prudential rules ... for the well ordering of the same, and the employment, relief, management and government of the persons therein placed .... and the correction of the refractory, disobedient and disorderly, by solitary confinement therein, and feeding them on bread and water only, as they shall deem expedient." tenBroek, California's Dual System of Family Law: Its Origin, Development, and Present Status, 16 Stav. L. Rev. 257, 296-97 (1964). Attempted escape from the poorhouse "resulted in solitary confinement and bread and water." Id. at 298. 
relations, and the attendant enclosure movement, but were literally driven from their homes and reduced to the status of "vagrants," "paupers," and "rogues." Nor, of course, was this process limited to England or to the sixteenth or seventeenth centuries. In 1776 Pitt said: "The poorest man may, in his cottage, bid defiance to all the forces of the crown. It may be frail; its roof may shake; the wind may blow through it; the storm may enter; but the King of England may not enter; all his force dare not cross the threshold of the ruined tenement."24

He spoke in terms of apparent universal application. But he obviously was not speaking of the destitute. The poorest man in Pitt's rhetoric at least had a cottage. But, as we know, large numbers of unfortunate persons had no shelter at all, from either wind or storm, let alone the King's men who seized them and placed them in orphanages, asylums, workhouses, poorhouses, jails, or saw to it that they became indentured servants. Within a few years of the enactment of the Elizabethan poor laws, in 1601, Shakespeare wrote "King Lear" in 1605-06. It is surely not accidental that Lear in the great storm scene in Act IV, Scene IV, before the hovel on the heath, addresses the unsheltered poor:

You houseless poverty ...

Poor naked wretches, wheresoe'er you are, That bide the pelting of this pitiless storm, How shall your houseless heads and unfed sides, Your looped and windowed raggedness, defend you From seasons such as these? O, I have ta'en Too little care of this! Take physic, pomp; Expose thyself to feel what wretches feel, That thou mayst shake the superflux to them, And show the heavens more just. ${ }^{25}$

II

POVERTY AND THE CONSTITUTION

\section{A. Early Developments}

The poverty-stricken constituted an exception not only to the ideals of English freedom but also to the protections of the Bill of Rights. That

23 See, e.g., Hmx, PuRIranism and Revolution, 219-27 (1964). "The vagabond class was drawn largely from evicted peasants: they were helpless in the new world of capitalist insecurity unless they had skilled labor power to sell." Id. at 227. "The problem set by vagabondage and vagrancy was to force men who had been deprived of their independent means of livelihood to enter into 'free' contracts to work for a capitalist employer, and to accustom them to the habit of steady work throughout the year. A new pattern of social discipline had to be imposed. . . . Poor relief must be associated with, and subordinate to, the imposition of the new discipline: houses of correction, family means tests, the apprenticing of pauper children to a trade, whether they or their parents wished it or not." Id. at 222.

24 Frank v. Maryland, 359 U.S. 360, 378-79 (1959) (dissenting opinion).

25 SHAkespeare, King Iear, Act TV, Scene TV. 
document though framed in a rhetoric of universal application, did not in practice or contemporary expectation apply universally. Part of the process of understanding the constitutional position of the poor today thus requires becoming acquainted with the historically antecedent attitudes and practices, which helped to condition their present position, and with all those forces, circumstances, and conditions, which inake for the gaps between our ideals $\mathrm{m}$ word and our hives in fact.

In America, the poverty-stricken, those denominated "vagrants," "vagabonds," "paupers," and "rogues" were deemed in law to be in theinselves, offensive. Such persons offended by their mere existence; they constituted a "inoral pestilence"; their very being was a form of "contraband." In the Articles of Confederation they had been classified together with fugitives from justice. ${ }^{26}$ Under the common law and the laws of the several states, they could be seized and jailed or otherwise denied freedom available to others. ${ }^{27}$ They could hardly be said, therefore, to have enjoyed a right to privacy in "their houses, papers and effects"-even assuming that all or some of these existed, the concept is merely ironic.

The legal depth of the degradation which poverty entailed during our early years as a nation can be seen clearly in the language and result of an early United States Supreme Court case, City of New York v. Miln, decided in $1837 .^{28}$

New York had passed legislation excluding poor persons from entry into the state. The issue was whether such an approach to the poor was within New York's police power and constitutional. The Supreme Court held that it was, making reference, in its opinion, to "the moral pestilence of paupers, ${ }^{, 29}$ and reasoning that it was as constitutional to take precau-

26 Articles of Confederation 1777, art. IV. See Bingham's 1859 speech in Congress (in opposition to the admission of Oregon into the Umion because of its constitutional provision that "no free Negro or mulatto, not residing in this State at the time of the adoption of this constitution, shall ever come, reside or be, within this State, or hold any real estate, or make any contract, or maintam any suit therein ...."): "I . . . refer gentlemen to the Journal of the Continental Congress, volume 2, page 606.... [I]n that Congress, on the 25th of -June, 1778, the Articles of Confederation being under consideration, it was moved by delegates of South Carolina to amend the fourth article, by inserting, after the word 'frce' and before the word 'inhabitants,' the word 'white,' so that 'the privileges and immumities of the citizens in the several States should be limited exclusively to white inhabitants.' The vote on this amendment was taken by States, and stood two States for, and eight against, and one equally divided. This action of the Congress of 1778 was a clear and direct disavowal that all free inhabitants, white and black, except 'panpers, vagabonds, atd fugitives from justice' (which were expressly excepted), 'were entitled to all the privileges and immunities of free citizens in the several States." Address by John A. Bingham, 1859, in TENBroEK, Equar UNDER THE LAW 320, 334, 336-37 (1965). (Emphasis added.)

27 See note 78 infra.

2836 U.S. (11 Pet.) 102 (1837).

$29 \mathrm{Id}$. at 142 . 
tions against the dangers of poverty by excluding the poor as it was to take similar police measures against "convicts" or "infectious articles."30 In the highest court in the land, poverty was thus seen to be a species of immorality; like crime or pestilence, it was within a state's police power; and poor persons were thereby placed on a par with convicted criminals and contaminated commodities.

Similar language to that employed in Miln continued to be "casually repeated in numerous later cases up to the turn of the century."31 Indeed, it was not until 1941, when the issue presented in Miln was again brought to the Supreme Court in Edwards v. California, ${ }^{\mathbf{2}}$ that the ligh court finally repudiated the equation of poverty with immorality. It had taken more than one hundred years for poverty stricken persons to progress, in the eyes of the law, from the dignity of treatment accorded to contaminated commodities to that of uncontaminated ones. Yet the decision marked a watershed in the development of our intellectual and legal attitudes toward poverty.

\section{B. The Turning Point}

The Edreards case, like Miln, arose over the issue whether California could constitutionally exclude the victims of the great depression from seeking new horizons in the "golden state." En route to its decision, the Court said that whatever may have been the view in 1837, "we do not think that it will now be seriously contended that because a person is without employment and without funds he constitutes a 'moral pestilence.' Poverty and immorality are not synonymous." ${ }^{\prime 33}$ To be sure, this was important language; it was indeed time to recognize that the mere condition of being without funds was neither a function of personal choice, necessarily, nor a mark of moral fault. But, unfortunately, its actual holding was drastically limited. The Court reasoned that interstate transportation of persons was "commerce"; that the exclusion of poor persons was not an exercise of a state's police power but a mere economic regulation; and since the contemplated exclusion burdened interstate commerce, the regulation of which was constitutionally reserved exclusively for Congress, California's law violated the commerce clause. Though doubtless a step in the right direction - the poor had at least been elevated to a level with noninfectious articles of comnerce-the $E d w a r d s$ decision shed little light on the question of the constitutional rights of the poor as persons beyond

80 Ibid.

81 Edwards v. California, 314 U.S. 160, 176 (1941).

82 Ibid.

33 Id. at 177 . 
suggesting that they were not to be regarded as immoral merely because of their poverty.

Justice Jackson alone rose to the occasion and, in a separate concurring opinion, undertook to set forth a general, theoretical consideration of the relationship between poverty and the Constitution. In pertinent part he said:

Does "indigence" . . constitute a basis for restricting the freedom of a citizen, as crime or contagion warrants its restriction? We should say now, and in no uncertain terms, that a man's mere property status, without more, cannot be used by a state to test, qualify, or limit his rights as a citizen of the United States. "Indigence" in itself is neither a source of rights nor a basis for denying them. The mere state of being without funds is a neutral fact-constitutionally an irrelevance, like race, creed, or color. ${ }^{34}$

Here was a new note! For the first time language in a Supreme Court decision recognized that there could be a contradiction between the fact of poverty and the constitutional guarantees of freedom. In insisting that the mere state of being without funds must be a constitutional irrelevance, Justice Jackson opened up the entire question of how the stubborn, brutal, and invidious fact of poverty was to be rendered constitutionally "neutral." What was inomentous in Justice Jackson's opinion was the understanding that no more legitimately than race or creed could poverty be suffered to diminish constitutional freedoms. To the extent that poverty did have that effect, it was itself unconstitutional! Freedom to have constitutional freedom thus implied freedorn from poverty.

\section{The New Approuch}

Before the Court was again confronted with the issue of the conflict between poverty and the Constitution, another fifteen years were to pass. Then Griffin $v$. Illinois, ${ }^{35}$ in 1956 , presented the question whether justice in the form of equal protection and due process of law required a state to provide a trial transcript at its own expense to an indigent convict who could not otherwise effectively take advantage of the right to appeal which Illinois made generally available to all who could afford it. The Court split on the question. Five justices thought that the guarantee of equal protection required Illinois to provide equal access to its courts of criminal appeal even if that meant paying for transcripts so the poor could have them. Four Justices, dissenting, questioned whether any state was constitutionally compelled to inake persons "economically equal before its bar of justice."

34 Id. at $184-85$.

35351 U.S. 12 (1956).

$36 \mathrm{Id}$. at 28 . 
curring opinion, asked rhetorically whether a state could constitutionally himit appeals from criminal convictions to those persons who could afford to pay a fee of five-hundred dollars. ${ }^{37}$ Justice Harlan countered by asking whether states were violating the Constitution in requiring tuition fees for admission to state colleges, though many who might otherwise choose to attend were thus excluded. ${ }^{38}$

Here was the Supreme Court seriously and forthrightly wrestling with the challenge which Anatol France had laid down years before when he questioned the value of a legal guarantee of equality in the face of economic facts which made realization of the guarantee by the poor impossible. The members of the Supreme Court were apparently agreed that where fundamental rights are concerned, the Constitution requires equality of access to them even if that means that the state must bear the cost. The justices divided over the question whether the right to appeal was a fundamental right or a mere luxury.

The stage was thus set for the question: Assuming that a person's poverty does stand in the way of a fundamental right; that poverty and only poverty blocks access to an aspect of justice which all agree is "implicit in the concept of ordered hiberty"39-under such circumstances, is a state constitutionally required to neutralize the fact of poverty, to "equalize" the poor man by providing the money or other necessities needed to realize the right?

Seven years later, in the landmark case of Gideon v. Waimworight, ${ }^{40}$ the Court provided the answer by unamimously holding that at least as to state prosecutions involving the possibility of a substantial prison sentence, due process of law requires that defendants have access to representation by counsel regardless of their ability to pay the fee. The Court's basic assumption was that the right to counsel in sucl circumstances is a fundamental riglit. The ability to hire the services of an outstanding attorney would, to be sure, still turn on the condition of a man's purse, as would access to other "luxuries." But, as to the riglit to be represented by a lawyer who can do an adequate job, it is the Constitution, not one's purse, which guarantees that.

In these few cases, legal attitudes toward the poor may be said to have taken a new direction pointing to a narrowing of the gap between the principle that fundamental rights belong equally to all and the persistent fact of second class citizenship for the poor. ${ }^{41}$ Tlough this new under-

\footnotetext{
37 Id. at 22 .

$38 \mathrm{Id}$. at 34-36 (dissenting opinion).

30 Cf. Palko v. Connecticut, 302 U.S. 319 (1937).

40372 U.S. 335 (1963).

41 See Ward, Law AND Poverty 1965, at 4 n.9 (1965): "There is, of course, as yet no constitutional right to counsel in civil proceedings .... Some have questioned the validity of the
} 
standing of the guarantee of equality and due process has thus far been applied only to the aspect of the conflict between poverty and constitutional rights bearing upon the process of criminal law, it is clear that the logic of these decisions extends to other areas. In the field of fundamental constitutional rights, as in the field of full employment, it appears that we are coming to understand that reliance is no longer to be placed in laissez faire. If the automatic forces of the market will not do the job, men must. And therefore the task now is to accelerate the process whereby the gap between principle and practice can be eliminated. It is time to move from dedication in principle to realization in practice of the Constitution's great guarantees of first class citizenship for all.

Some speculation may be justified as to the extent to which the logic of Griffin and Gideon will require economic support from the government to be furnished to persons outside the area of criminal law. The most fundamental needs are clearly for food, shelter, and clothing. To what extent are they merely luxuries and to what extent are they not only biological and social but also constitutional necessities?

It would be perverse to say that one has a fundamental right to be assisted by a lawyer wlien charged with crime, but that he has no right to such food or medicine as might be required to keep him reasonably healthy and attentive during the process of his trial. If the defendant is a diabetic who requires insulin in order to stay out of a state of shock it would seem that the constitutional right to a fair trial would require him to be supplied with insulin in the same way that it would entitle him to be furnislied with counsel. But if a person charged with crime has a right to such assistance, on what principle is one innocent of such a charge to be denied equal access to assistance? Is a person's right to meaningful participation in the processes of citizenship less fundamental than one's right to defend himself when accused of crime? What constitutional guarantees other than those which are bound up with the criminal law are denied to persons because of their poverty? Does the fourth amendment's guarantee of the right to be secure in one's person, papers, house, and effects presuppose housing for the people of America? If it does, then clearly the condition of being unable to pay rent can deprive one of this aspect of the right to privacy as effectively as the inability to pay counsel fees could, prior to Gideon, deprive one of the right to counsel. Does not the right to privacy therefore inply that poverty can not constitutionally be allowed to stand in the way of minimally adequate housing? If poverty

distinction ...." Former Attorney General Kennedy, for example, in his Address on Law Day at the University of Chicago Law School, May 1, 1964 said: "We have securcd the acquittal of an indigent person-but only to abandon him to eviction notices, wage attachments, repossession of goods and termination of welfare benefits." Ibid. 
is to be a constitutionally neutral fact, it must not deprive persons of the guarantees of the fourth amendment any more than of the other fundamental guarantees. Moreover, if the answer here is in the affirmative and the state is under a constitutional obligation to provide persons with housing, are there not some minimal requirements whicli must be adhered to so that the right is meaningful? For example, if the state must provide a transcript, obviously it need not be bound in leather, but it must be reasonably accurate and legible; if the state must provide a lawyer, obviously he need not be the attorney general, but he must be reasonably competent; if the state must provide housing for those who would otherwise be without shelter, it obviously need not be the governor's mansion, but it must be minimally consistent with basic standards of health and decency. Clearly neither the poorhouse nor the jailhouse will constitute housing which is meaningfully relevant to the constitutional riglit to privacy. If rat infested, dilapidated, oppressive slum dwellings can produce disease, depression, and other mental disorders and render privacy even in the sense of access to reasonable seclusion meaningless, ${ }^{42}$ such dwellings do not constitute housing in the sense required in order for the right to privacy not to be a mockery of constitutional protection.

To be sure, considerations such as these point in the direction of deep changes in the interpretation of our constitutional law. But this is no more than what the Constitution itself requires. Indeed, as the late Justice Frankfurter once said, "it is the very nature of a free society to advance in its standards of what is reasonable and right. Representing as it does a hiving principle, due process is not confined within a permanent catalogue of what may at a given time be deemed the limits or the essentials of fundamental rights." ${ }^{43}$ Moreover, the economic shift from a laissez faire to a welfare state system requires appropriate changes in legal conceptions in order that the law may remain viable. However questionable the old assumption that there is no state action in or responsibility for the ordinary processes of economic life may have been prior to the New Deal, there is today no doubt that government policy is highly relevant to, if it does not wholly determine, the degree of the realization or frustration of virtually every basic human need. From stagnation to accelerated growth

42 See Paudsen, The Legat Needs of the Poor and Fanduy Law 18, 20 (1964): "A small unattractive apartment in the heart of New York City on a hot summer's day can produce mental troubles almost by itself."

"Positive motivation withers in the midst of rats, refuse strewn alleys, peeling plaster, broken windows, cold radiators, and leaky ceilings. Nearly 1,000 adults and children live in one slum block of the District of Columbia." WAID, op. cit. supra, note 41, at 13. Another stimulus to "positive motivation": "Negroes are apt to pay up to 30 percent more rent for the same facilities as white tenants." Ibid, citing MAY, THE Wasted Aurericans 131 (1964).

43 Wolf v. Colorado, 338 U.S. 25, 27 (1949). 
rates, unemployment to full employment, miserably inadequate to minimally decent housing, polluted air and water to fresh air and clean streams and bays-in almost every way that men measure welfare, the Great Society not only assumes but proclaims that the guiding hand is neither invisible nor anonymous but the government's.

Since it is clear that the level of employment, or the character of education, or the nature of housing is a reflection of policy; since we know, for example, that budgeting twelve billion dollars will bridge the so-called "poverty gap"; 44 that, in sliort, there is no greater inevitability to growing

44 Depending on the figures one uses, either one-fifth or two-fifths of the American people are poverty-stricken. According to the President's council of economic advisers, the poverty line for an urban family of four is about $\$ 3,000$ in annual income. This is a pretty low floor as can be seen from the fact that such a budget will allow a daily expenditure of seventy cents per person for food and a dollar and forty cents for all other needs including rent, clothes, medical care, etc. See Miller, Who Are The Poor, 200 Tre Narron 609 (1965). Still, according to the 1960 census, the families constituting the lowest fifth of the income hierarchy received less than $\$ 2,798$ annually. According to the Heller Committec For Research in Social Economics of the University of California, a "modest but decent" annual income for such a family would be $\$ 5,500$ to $\$ 6,500$ depending on the city of residence. According to the 1960 census figures again, the families constituting the second lowest fifth of the income hierarchy had incomes between $\$ 2,798$ and $\$ 4,812$. Taking the poverty line at the official $\$ 3,000$ figure thus leaves a fifth of the American people in limbo between poverty and decency, and classifies about 34.5 million persons as poverty-stricken, subsisting at incomes below this minimum poverty line. In 1963 these persons (balf of whom are children) received an aggregate income that was about $\$ 12$ billion below their estimated minimum requirenıents. This is the so called "poverty-gap."

Given the fact that the government has not appropriated even a twelfth of this sum for the annual budget of the war on poverty, it must unfortunately be concluded that so far, at least, the war is more talk than fight. The need is to prevent the "war" from degenerating into mere propaganda: We must do what we can to see to it that the words are matched with deeds. That will almost certainly depend on the amount of attention the poor themselves are able to focus upon their needs. For it scems pretty clear that, as Alan Harrington remarked recently, the war on poverty has been a reaction to the pressures generated by the civil rights revolution, and would not otherwise have occurred.

Who are "the poor"? About two million families, a fourth of the poor living below the poverty line, are headed by persons who work full time. "This figure dramatizes the fact that Iow wages are still a major cause of poverty in the United States." Miller, supra at 610. Another million and a balf family heads work at full time jobs but are not cmployed an entire year becanse of illness or layofis. About two million families, another quarter of the poor, are headed by women. Miller estimates that about $\$ 5$ billion would bring all families leaded by women up to the minimum poverty he requirenients. Right now bowever, though $\$ 260$ per month is the minimun necessary standard for a family of four beaded by a wonian, only three states set their minimun budgets at or above this level. In several states the median AFDC standard for such a family was $\$ 150$ and for the country as a whole it is $\$ 203$. Even so, only "nineteen states actually make payments sufficient to bring all cligible AFDC families up to their own excessively modest minimums. The others set dollar maximums on the payments to any one family, regardless of size or needs, or, for fiscal reasons pay only a percentage of the sum that elaborate investigation has shown to be needed." Sec Burns, The Poor Need Money, 200 The Nation 613-14 (1965).

Though the nonwhite population is about $11.8 \%$ of the total, about $25 \%$ of the poor are nonwhite. The meaning of these figures takes on further significance when it is realized that 
up absurd in Harlem or Watts than there was in Autherine Lucy or James Meredith being denied college educations, it follows that the government is constitutionally responsible in these areas in a way which the law must recognize upon pain of losing contact with reality. When former Attorney General Kennedy declared that twenty per cent of our population is "serving a hife sentence of poverty" his words accurately implied that a conscious choice, a negligent or deliberate policy condemns these millions. But by what constitutional authority may they be so "convicted"? If a legislative refusal to appropriate twelve billion dollars is the cause of their condemnation, are they not being punished unconstitutionally? Have they not been deprived of a judicial trial? Have they not been subjected to what is in effect a bill of attainder? Have they not been sentenced to cruel and unusual punishment? Are they not deprived of equal protection and due process of law?

Attorney General Katzenbach has noted the inequality between the poor and the comfortable in relation to the law. "To us," he said, "laws and regulations are protections and guides, established for our benefit, and for us to use. But to the poor, they are a lostile maze, established as harrassment, at all costs to be avoided." 46 Former Attorney General Kennedy went further. "The poor man," he said, "looks upon the law as an enemy, not as a friend. For him the law is always taking something away." 47 The law, as it were, is "separate" but hardly equal. Attorney General Katzenbach has added: "Small wonder then that the poor man

in 1940 the unemployment rates were $13 \%$ and $14.5 \%$ for whites and nonwhites respectively. By 1962 the corresponding figures were $4.9 \%$ for whites and $11 \%$ for nonwhites. Though Negro unemployment was only $12 \%$ above white in 1940 , it was $125 \%$ greater in 1962 . This reflected the fact that as unemployment increased after the war, it tended to concentrate among the unskilled and semi-skilled for various reasons, mainly the impact of the new technologies. In any event, the "race-gap" had grown approximately tenfold! Another aspect of this process appears in the fact that the gap between the earnings of Negro and white workers has grown steadily since the end of World War II. S. Doc. No. 86, 88th Cong., 2d Sess., 38 n.2 (1964); Setect Subconnc. on Poverty of the Compr. on Labor and Public Welfare, The War on Poverty, A Comptcation of Matertats Relevant to S. 2642, at 38 n.2. In the hight of such trends it should surprise no one that $44 \%$ of all recipients of Aid to Needy Children are Negro, more than $80 \%$ in ten northern cities. MAY, THE WASTED AMERICANS 23 (1964).

It is therefore to be expected that the drive for equality which has so rearranged the constitutional topography of the United States; this revolution in constitutional theory and law which has even driven the courts into reapportionment of political districts; this civil rights revolution is also going to compel us to come to grips with the relation between poverty and the constitution.

45 Quoted in address by Attorney General Katzenbach in Justice, Justice, Shall Ye Pursue, to the Conference on Extension of Legal Service to the Poor, Washington, D.C., Nov. 12, 1964, p. 6.

40 Quoted in WaID, op. cit supra note 40 , at $6 \mathrm{n} .14$.

47 Id. at n.13. 
does not respect the law. He has little reason to believe it is his guardian; he has every reason to believe it is an instrument of the Other Society, of the well-off, the well-educated, the well-dressed, and the well-connected. The poor man is cut off from this society-and from the protection of its laws. We make of him a functional outlaw."48

But if as the Supreme Court said in the school desegregation cases, "separate" is "inherently unequal" even though "similar," what shall we say of it when it is hostilely dissimilar? If inequality generates in Negro students sent to segregated schools "a feeling of inferiority as to their status in the community that may affect their hearts and minds in a way unlikely ever to be undone, ${ }^{349}$ what shall we say of a system of law which strikes fear into the hearts and minds of the poor, which appears to them as a "hostile maze," "an enemy," and "at all costs to be avoided"?"o

Such wrongs require remedies. This is not, of course, to suggest that immediate litigation of these questions is necessarily either possible or desirable as a strategic matter. But that is not the point here. Historically, the appeal to constitutional rights has served the needs of the poor and oppressed as a rallying cry, an inspiration, an ideal even though the courts denied that there were such rights as were appealed to. Nevertheless, the energies which were thus kindled brought ultimate success to the struggle for constitutional change and progress. From the abolitionists and sufragettes to the NAACP, CORE, SNCC, and The Welfare Rights Organization, the cry for justice, the demand for freedom, equality, and dignity has invoked, and derived power and sustenance from, the notion of constitutional entitlement. If there is to be a war against poverty, let us help to make it as effective as possible. It is clear that the poor will themselves have to bear the major brunt of the struggle, but we of the legal profession can help. As Attorney General Katzenbach has said, "One of the threshold problems in this new area is simply to make rights known. . . . For a poor person to hold rights in theory satisfies only the theory. We have to begin asserting those rights-and help the poor assert those rights. Unknown, unasserted rights are no riglits at all." ${ }^{11} \mathrm{We}$ can show how the logic and the history, the rhetoric, and even some precedents regarding freedom, equahity, and justice are with the poor whether or not courts are yet prepared to vindicate their rights. As we work together in these ways, we shall hasten the process of vindication. But, if this is not done, the law and the Constitution can not but seem at best to be irrelevant to and at

48 Address by Attorney General Katzenbach to the National Conference on Law and Poverty, June 1965.

49 Brown v. Board of Educ., 347 U.S. 483, 494 (1953).

50 WaId, op. cit. supra note 41, at 6 n.14.

51 Katzenbach, supra note 45, at 10-11. 
worst a mockery of the deepest needs and hopes of millions of Americans. In a profound sense, the war against poverty is a war in defense of the constitution.

\section{III}

\section{THE MEANS TEST, CHARITY, AND UNCONSTITUTIONAL CONDITIONS}

Charity implies discretion. It presupposes the power to withhold as well as grant. When the means of existence may be manipulated, withheld, granted, those who have power over the means, also lave power over the persons dependent upon those means. But, to speak of some having the power to withhold or grant the means of other's existence, is to speak of slavery. Nor is slavery inconsistent with charity. History informs us that benevolence has been found in all forms of despotic, institutions. For charity depends upon power; indeed, it presupposes the existence of a great inequality of power as between the giver and the taker of charity. Charity in this sense therefore presupposes despotism. And while despots may be cruel or benevolent, it is their power to nuake the choice which earns them that title. Given despotic conditions, charity may certainly be ameliorative. But charity does not square with freedom. Historically, when paupers were regarded as criminals, or at least as immoral, it was taken for granted that they had either forfeited or failed to earn the rights of respectable citizens. Unlike the latter, they were not only not entitled to privacy, they were lucky to avoid imprisonment. When provided with charity in the form of shelter, they discovered that a house is not a home if it is a house of correction, an almshouse, or a poorhouse.

In any event, one who depends upon charity is one who depends upon the goodwill of a master. One who depends upon the goodwill of a master niay be a slave, but he cannot be a free man; dependence is incompatible with independence; being forced to please another, one is precluded from pleasing himself. All this defines a condition whicl is the very opposite of that which the right to privacy is intended to protect. The principle of charity is at war with the principle of privacy, just as the principle of slavery was at war with the principle of equality, or freedom, or democracy. ${ }^{52}$

$52 \mathrm{An}$ exchange of correspondence between a slaveholder and her fugitive slave, published in the Liberator, April 27, 1860, is illustrative. The slaveholder wrote: "I write you these lines to let you know the situation we are in, - partly in consequence of your running away and stealing Old Rock, our fine mare. Though we got the mare back, she never was worth much after you took her;-and, as I now stand in need of some funds I have determined to sell you and I have bad an offer for you but did not see fit to take it. If you will send me one thousand dollars, and pay for the old mare, I will give up all claim I have to you. ... If you do not comply with my request, I will sell you to someone else, and you may rest assured that the time is not far distant when things will be changed with you.... You know that we reared you as we reared our own children; that you was [sic] 
The abolitionists believed and argued that slavery violated the fundamental basis upon which governments are instituted, the protection of the natural rights of men. Slavery was in their view, therefore, in violation of the political philosophy which underlay the establishment of our government, the basic and self-evident truth that all men are created equal and are endowed with inalienable rights of life, liberty, and the pursuit of happiness. Since on this view, the Constitution was an instrument which was created in the light of and to protect these values, slavery, which was at war with them was also in conflict with the constitution even prior to the Civil War amendments. ${ }^{53}$

The abolitionists did not, however, campaigu against poverty or the treatment of the poor. The propagandists of the slaveowners tried to respond to antislavery arguments in part by arguing that the slave was better off than the wage worker; that the conditions of his existence frequently reduced him to a level of poverty rendering his circumstances at best similar but generally inferior to those of the chattel slave. But the propaganda was not very effective. The conditions of poverty in which the wage worker might find himself were impersonal. They were not permanent. They were not a function of any individual's or group's policy; indeed the assumption was that no individual or group of individuals had any control over these matters. Moreover, the existence of the frontier and the dynamic and open character of the society legally and economically provided a substantive basis for individual hope, freedom, dignity, even when down and out.

In today's America, practically all of these conditions are, if not reversed, radically changed, and poverty increasingly takes on the aspects of slavery. Today it is not the impersonal and inscrutable forces of the market which determine the character of the hives of the poor and their

never abused, and that shortly before you ran away, when your master asked if you would like to be sold, you said you would not leave him to go with anybody." The fugitive slave replied: "You say you have offers to buy me, and that you shall sell me if I do not send you $\$ 1,000$, and in the same sentence, you say, 'You know we raised you as we did our own children.' Woman, did you raise your own children for the market? Did you raise them for the whipping post? Did you raise them to be driven off, bound to a coffle in chains? Where are my poor bleeding brothers and sisters? Can you tell?. . . But you say I am a thief because $I$ took the old mare along with me. Have you got to learn that $I$ had a better right to the old mare, as you call her, than Manesseth Logue had to me? Is it a greater sin for me to steal his horse, than it was for him to rob my mother's cradle, and steal me? If he and you infer that I forfeit all my rights to you, shall not $I$ infer that you forfeit all your rights to me? Have you got to learn that human rights are mutual and reciprocal, and if you take my liberty and life, you forfeit your own liberty and life? Before God and high heaven, is there a law for one man which is not a law for every other man?" Quoted in Aptheker, A Doctmentary History of the Negro People in the United States 449-5I (1951).

53 See tenBroek, supra note 22. 
destiny; it is not a matter of the invisible hand arranging their fate; but rather the legislative and bureaucratic hand of state. Policy, law, regulations, administrators, social workers, probation officers-these are the responsible and manipulative personal forces which shape the hives of millions; not the invisible hand of fate, but the accountable power of governinent.

But if that power is accountable, to whom is it accountable? The unfortunate fact is that this power, which theoretically is accountable to all citizens, is not accountable to the poor, but it is rather the other way around. Because the welfare program is so largely constructed on the principle of charity as embodied in the means test approach, those who dispense the means of existence virtually maintain the recipients of welfare in a condition of bondage. Incurring the ill will of sucll persons can result in deprivation of desperately needed funds, being forced to change one's deepest habits, ${ }^{54}$ or even losing one's children or going to jail. Even if welfare grants were adequate to the task of allowing for the acquisition of the plyysical prerequisites of privacy, the conditions under which they are dispensed would destroy the possibility of achieving it.

Free men are those who have and use the power to manage their affairs in accordance with their own judgment; they determine for themselves whether their needs are being met. That must be the direction in which power is accountable in a free society. But the basis upon which welfare benefits are distributed is directly contrary to these assumptions: Need is judged not by the recipient of the grant, but by its dispenser; moreover, the grant varies with the dispenser's judgment of the existence, size, and character of the need and also the character of the recipient. The means test or charity principle upon which welfare assistance is based, thus violates and is utterly incompatible with the riglit to privacy because the latter is centrally concerned with the freedom to be an individual, a functioning member of a self-governing community, while the means test renders impossible "the direction of one's affairs, the whole basic principle of self-management." ${ }^{355}$ Twelve years ago, tenBroek and Wilson in a seminal article ${ }^{56}$ masterfully analyzed the contradiction between these principles:

54 "Appellant also argues that he has a right to live as he pleases .... One would admire his independence if he were not so dependent .... One is impressed with appellant's argument that he enjoys the hife he leads in his humble 'home' as he calls it . . . .

"It is true, as appellant argues, that the hardy pioneers of our country slept in beds not better than the one he has chosen, ... but unlike the appellant, ... they did not call upon the public to support them ...." Wilkie v. O'Connor, 261 App. Div. 373, 375, 25 N.Y.S.2d 617,619 (1941).

55 tenBroek \& Wilson, Public Assistance and Social Insurance-A Normative Evaluation, 1 U.C.L.A.L. REv. 237, 264 (1954).

${ }^{56}$ Ibid. 
Under it [the means test], the individual recipient soon loses control of his daily activities and the whole course and direction of his life. The capacity for self-direction presently atrophies and drops away. It is the welfare agency rather than the individual which decides what wants shall be taken into account. It is the welfare agency which decides what needs shall be budgeted. It is the welfare agency which decides how much shall be allocated to meet each of them. The smallness, character and scrutiny of the budget result in a welfare agency domination of a supposedly free consumption choce and a corresponding frustration of the principle of cash payments. It is the welfare agency, moreover, which decides what resources are to be treated as available for the individual's support and how he is to utilize them for that purpose. The agency tells him when, how and in what circumstances he can dispose of his property, what returns he must get and the manner of its payment. In these circumstances, it is an idle formalism to say, as many state statutes and rules do say, that the payment is an over-all amount no part of which is required to be spent for any given purpose or that there shall be no dictation as to where and how a recipient shall live. The formal sanctions are there and are compelling. If the recipient does not live up to the conditions and do so with alacrity, he may be removed from the rolls or have his budget reduced. The alternatives are thus obedience or starvation. The informal sanction-consisting of the social worker's participation in the recipient's affairs-are also there and are no less continuing and impressive than the formal. With each new item budgeted or eliminated, with each new resource tracked down and evaluated, the social worker's influence increases. This is an inevitable concomitant of the means test. It results from the nature and extent of the system. It is bred and nourished by the provisions of the statutes and the rules issued under them. It is in the flexible joints of the cumbersome machinery. It is in the inescapable confinements of the budget. It is in the idleness, defeatism and waning spirit of the recipient. Whatever the social worker's wishes and intentions, her hand becomes the agency of direction in his affairs. . . .

... [D] ignity is jeopardized by the initial investigation, by the searching inquiry into every intimate detail of need, living habits, family relations, by the setting up of a detailed budget of expenditures subject to repeated examination and review, by the continuously implied and often explicit threat that if behaviour is uncooperative or unapproved, aid will be reduced or stopped ... and, finally by the constant tendency of the whole system to push living standards down below a minimun of decency and health.

... [M] eans test aid is fundamentally antithetical to the idea of equality. A system which makes so much depend upon a minute examination of every aspect of the individual's situation necessarily involves personalized judgments by officials and invites arbitrary and whimsical exercises of power, prevents the enforcement of a uniform rule . . . renders it impossible for the recipient himself to determine to what he is entitled ... for complying with the purpose of providing a minimum standard of living, disability and absence of income, or age and absence 
of income [the latter can easily be determined from income tax returns] are the factors of relevance in determining eligibility. Equality requires that all who possess them should be treated alike. In this regard, means test aid stands in striking contrast not only to the requirements of equality but also to the manner in which assistance is granted to other groups: to youth by public education; to farmers by parity payments and other assistance; to industrialists and others by tariffs; to labor by minumum wages. In none of these cases is aid granted by an individual means test or by an invasion of rights of self-management in personal affairs. Assistance is upon a group basis, with need determined or presumed from characteristics of the group or situation in which they find themselves and with allocations of aid upon a fixed grant formula. ... .

... Since means test aid requircs that all income and resources of the recipient be applied to meet his current needs, and since the public assistance grant is reduced by the amount of any such available income or resources, the usual financial motive for effort and endeavor is removed..$^{57}$

It is sometimes said, by persons of good will, that the "means test" is simply a name for government's efforts to prevent cheating; that it is a necessary and common device, encountered, for example, in the income tax; and that it does not discriminate against the poor. The point which such criticism misses is that a test which considers means is not necessarily a means test. Surely, the income tax considers "means." But it is not a means test. A means test concerns itself with the question whether an individual or a family has sufficient resources (including everything from labor power, to a change in consumer values and tastes, to savings) to justify denial or dininution of assistance to help secure the bare minima of existence. Such a question always and necessarily involves the substitution of the welfare agent's judgment and infornation for that of the recipient's. The agent in a real sense thus becomes the recipient, taking over his most intinate and basic functions, pre-empting his freedonl, dignity, and hunanity and destroying his privacy. This is not the case in any sense in the other situations where "means" are considered, as in the income tax. First, the income tax does not even attach unless some minimal incone, exenipt from taxation, is exceeded. As to the excess, the way it is handled is strictly the taxpayer's business. Moreover, in addition to being mdependent in the ways he chooses to use his income, he is also independent of the threat of having his necessaries cut off if he does not please some agent who thinks he knows better than the taxpayer how his income and resources should be deployed. Indeed, the tax agents may not search financial records without a court order if the taxpayer chooses to

67 Id. at 264-66. 
resist scrutiny. ${ }^{58}$ Not only is such resistance not a matter of losing the bare necessities of existence, but once a court order issues, permitting such searches, they are strictly and narrowly limited to financial records; they have no bearing upon such questions as how a mother is to bring up her children; whether she should work or stay home; how much rent is within reason; what sort of neighborhood she may live in; whether she may move; what resources her relatives possess; and whether she is having an affair.

These are the reasons why the means test approach of our current welfare practices and the laws and regulations which require and sanction them are incompatible with the right to privacy and other fundamental constitutional guarantees. ${ }^{50}$ The means test should therefore be stricken from our welfare programs as an unconstitutional condition. Striking the means test would at the same time eliminate other unconstitutional practices such as midnight raids, relatives responsibility requirements, and residence requirements. But the charity principle still will linger in the inadequacy of the grants themselves, and this will require a different constitutional attack.

Unconstitutional conditions may not be attached to rights, privileges, or gratuities. In the recent case of Torcaso v. Watkins, ${ }^{60}$ the Supreme Court said that this point was "settled by our holding in Wieman v. Updegraff .... We there pointed out that whether or not 'an abstract right to public employment exists,' Congress could not pass a law providing 'that no federal employee shall attend Mass or take any active part in missionary work.' "In Sherbert v. Verner, ${ }^{61}$ the Supreme Court further

58 Cf. United States v. Powell, 379 U.S. 48 (1964).

59 In Department of Mental Hygiene v. Kirchner, 60 Cal. 2d 716, 388 P.2d 720, 36 Cal. Rptr. 488 (1964), the responsibility of relatives provisions were striken out of the California law dealing with the mentally irresponsible. The Cahfornia Supreme Court held that public responsibility for the nentally ill requires the costs of that responsibility to be borne by the public and that "a statute obviously violates the equal protection clause if it selects one particular class of persons for a species of taxation .... [for the cost of programs properly benefiting the public] cannot be arbitrarily charged to one class in the society." Id. at 722, 720, 388 P.2d at 724, 722, 36 Cal. Rptr. at 492, 490. It can be argued, also, that the neans test as a whole, which Professor tenBroek has shown to be largely motivated by cost-cutting considerations and thus to constitute a species of regressive and special taxation, violates the guarantee of equality. Certainly the provision of assistance to the aged and the families with needy children for example is as valid a public function as the hospitalization of the mentally irresponsible. And certainly it is as valid a public function as the provision of public schools, or assistance to farmers. Yet the latter, though similarly situated with reference to public support and benefit, are not treated the way welfare recipients are, either with respect to the financial or the privacy aspects of the means test. The classification of welfare recipients is therefore arbitrary and invidiously discriminatory and violative of the guarantee of equal protection.

6036 U.S. 488, 496 (1961).

61374 U.S. 398, 404-05 (1963). 
pointed out that "it is too late in the day to doubt that the liberties of religion and expression may be infringed by the denial or placing of conditions upon a benefit or privilege ... . In Speiser v. Randall ... we emphasized that conditions upon public benefits cannot be sustained if they so operate, whatever their purpose, as to inhibit or deter the exercise of First Amendment freedoms."

Where fundamental constitutional rights are involved, such as the right to privacy, "conditions upon public benefits cannot be sustained if they so operate, whatever their purpose, as to inhibit or deter [their] ... exercise ...."

There can be no question but that the conditions labeled the "means test" under which welfare benefits are distributed "inhibit or deter" the exercise of the right to privacy. It is clear that these conditions not only inhibit and deter but violate this fundamental riglit. The mucli publicized midnight raids in the course of which teams of fraud investigators ransack the homes of welfare recipients looking for "men in the home" are clearly unconstitutional violations of the fourth amendment, as Reich has shown. ${ }^{63}$ Yet such raids are only the most spectacularly unconstitutional aspects of the means test approach. A simple declaration of the unconstitutionality of the means test principle would render the entire machinery of man-hunting, the complete cop-kit of fraud investigators, bedroom snoopers, child disturbers utterly irrelevant to the welfare process, as indeed they are now except for their deleterious effects upon any of the legitimate or constructive purposes of welfare. Doubtless test cases now pending will result in a judicial declaration of the unconstitutionality of midnight raids. ${ }^{84}$ The danger inherent in this situation is that persons concerned with the protection of privacy will feel that the problem will have been solved since the most visible manifestation of the abuse of the right will have been stopped. But the subsurface part of the iceberg will not have been disturbed by such a victory and the danger is that in the legitimate celebration of sucls a genuinely significant step forward in the vindication of the fundamental rights of Americans and of the principle that the condition of a man's purse should not condition his fundamental rights, the unfinished task will be forgotten.

It is important therefore to emphasize that the means test is unconstitutional as a violation of or at the least a deterrence to or inhibition upon

$62 I d$. at 405 . (1963).

${ }^{63}$ Reich, Midnight Welfare Searches and the Social Security Act, 72 YALE L.J. 1347

64 Parrish v. Civil Service Comm'n, 1 Civil no. 22, 556, 1st Dist. Cal., appeal filed Jan. 7, 1965. Benny Parrish, a social worker, was fired for insuhordination when he refused on legal and constitutional grounds to participate in a mass "bed check" operation conducted by the Alameda County Welfare Department in January 1963. 
the exercise of the right to privacy. The only justification which can be brought forward in support of the means test approach is that by using it the state can shave the costs of the program. What is balanced against the fundamental right to privacy, therefore, is the state's interest in economy. Long ago in the case of Schneider v. Irvington, ${ }^{65}$ Justice Roberts pointed out that fundamental civil liberties were not to be endangered on grounds of economy. Doubtless the requirements of the fourth amendment add to the costs of operating government; but no court would entertain the suggestion that the use of warrants be curtailed because it would be cheaper to dispense with the use of judges. The costs of protecting fundamental rights are real enough and they must be borne. It is doubtful that an argument could be persuasively constructed to suggest that a justification for the means test is the state's right to "rehabilitate" welfare recipients. If the poor are not by the fact of their poverty rendered immoral, their poverty can hardly serve as a justification for discriminating between them and the rest of the population in moral terms. Rehabilitation, if it is to be meaningful, can not be properly approached punitively. The means test is an outgrowth of outworn and unconstitutional assumptions such as the assumption that poor persons are morally responsible for their plight and that their bad character needs careful scrutiny in order to prevent cheating.

In any event, the state must bear the burden of proof if it wishes to save a practice which violates, inhibits, or deters fundamental rights. This is a particularly heavy burden: "[W] here there is a significant encroachment upon personal biberty, the State may prevail only upon showing a subordinating interest which is compelling." ${ }^{" 16}$ Such a practice or law must be shown to be "necessary, and not merely rationally related, to the accomplishment of a permissible state policy." renders it virtually impossible for the means test to withstand a constitutional assault in the name of the right to privacy because there is no necessary connection of the sort required. The test for the presence of a necessary connection rather than a rational relation is the test as to whether the state can prove that no alternative methods are available to it whereby it can serve its legitimate purposes without violating, inhibiting, or deterring fundamental rights. ${ }^{68}$ Does the state desire to rehabilitate persons? The alternative of making teachers and schools and employment of an attractive character available to the recipients can certainly not be shown to be unavailable. What evidence can the state offer that such alternatives are

65308 U.S. 147 (1939).

68 Bates v. City of Little Rock, 361 U.S. 516, 524 (1960).

67 McLaughlin v. Florida, 379 U.S. 184, 196 (1964).

68 Sherbert v. Verner, 374 U.S. 398 (1963). 
not viable? "Mere legislative preferences or beliefs may well support regulation directed at other personal activities, but be insufficient to justify such as diminishes the exercise of rights so vital to the maintenance of democratic institutions." Finally, "precision of regulation must be the touchstone in an area so closely touching our most precious freedoms."70 Even "though the governmental purpose be legitimate and substantial, that purpose cannot be pursued by means that broadly stifle fundamental personal liberties when the end can be more narrowly achieved. The breadth of legislative abridgment must be viewed in the light of less drastic means for achieving the same basic purpose."71 The essence of the means test inheres in the amount of discretion vested in official persons to make determinations about the lives of others. As we have seen, this is as broad a power as the right which the recipient would have, under normal circumstances, to determine his own needs, likes, and desires. This hardly comports with the "precision" required of regulation in areas so "closely touching our most precious freedoms." This is not precision but annihilation. The breadth of this power may also be appreciated by viewing it from a slightly different angle of vision. As a condition of receiving assistance, mothers of needy children unust "cooperate" with the district attorney's office, ${ }^{73}$ generally for purposes of locating absent fathers. As a result, many county law enforcement officers use lie detectors on AFDC mothers and fathers. ${ }^{74}$ An opimion of the California legislative counsel states that "the use of such a device ... suggests a refusal on the part of the county to accept an applicant's statements as truthful and certainly does not demonstrate respect for the integrity and self esteem of the applicant." versal of the presumption of imiocence and the tendency to supervise totally, to maintain total surveillance, and thus progressively to undermine the right to the point of extinction. ${ }^{76}$

69 Schneider v. Irvington, 308 U.S. 147 (1939).

70 NAACP v. Button, 371 U.S. 415,438 (1963).

71 Shelton v. Tucker, 364 U.S. 479, 488 (1960).

72 NAACP v. Button, 371 U.S. 415,438 (1963).

73 See, e.g., Cax. Wetrare \& INST'NS CODE \$ 11477.

74 See tenBroek, California's Dual System of Family Lav: Its Origin, Development, and Present Status, 17 Stan. L. Rev. 614, 666 (1965).

75 Opinion of the California Legislative Counsel No. 4247 (July 15, 1960), quoted in tenBroek, supra note 53.

76 Compare the recent statement of Gunnar Myrdal at a national conference on poverty held at the University of California, Berkeley, February 26-28, 1965: "The social security system, including the provision of health facilities for all who need it, has to be reformed in a radical fashion. Incidentally, I believe somebody slould look into the history of social security in America and how it is continually imprisoned in out-dated conceptions. I think it is too closely related to that old man Bismarck and our old friend Lloyd George, who were pioneers in this field, but who characterized the social problen as eine Arbeiterfrage. 
The means test, it must be concluded, is an unconstitutional condition parasitically fastened upon and destructive of the privacy of millions of Americans.

\section{IV}

THE UNCONSTITUTIONALITY OF INADEQUATE WELFARE GRANTS

The right to counsel is guaranteed by and is an obligation of government. The obligation can be discharged in two ways, either through the "private" arrangements which usually suffice to make it possible for those who desire counsel to employ a lawyer, or through "public" provision of the services of lawyers for those who cannot privately arrange for them.

In the same way, the right to privacy is an obligation of government. Though private arrangements generally have sufficed with regard to securing this right for very many, it is understood that where private arrangements prove inadequate, government provision must fill the gap.

As we lave seen, unconstitutional conditions, such as requiring those for whom counsel is to be provided to adhere to a particular religion, may not be attached to the provision of any governmental service wliether it is the provision of an obligation or a gratuity. That would merely be to attempt to do indirectly what could not be done directly.

The direct governmental obhigation to provide counsel to those who cannot privately engage a lawyer is capable of being subverted in many ways: one, of course, is the method of requiring the forfeiture of another constitutional right as the price of providing this one-as in the example of the forfeiture of religious freedom; another, is simply the insufficiency of the very right ostensibly being furnished-as, for example, would be the case if the lawyer provided to an indigent defendant were inadequately trained to do the job. ${ }^{77}$ And, of course, the same result would obtain if the government flatly declined to furnish a lawyer at all.

In the same way, the governmental obligation to protect the riglit to privacy can be variously subverted and undermined. Certainly, no one would deny that the government could not constitutionally require adherence to a particular religion as a condition of furnishing food or sleelter to the destitute. Neither would anyone contend that the government could constitutionally require all shelters furnished to the indigent to be bugged and equipped with hidden cameras for the purpose of providing the welfare authorities with the opportunity for total surveillance. By the

I am proud that in my own country, Sweden, when we inaugurated an old-age pension reform in 1911, the labor party was eager to stress that we did not want to have the benefits subject to any condition except residence in the country. We wanted to give security to all as a right of citizenship. . . . This, of course, also simplifies the whole administration." Quoted in Gordon, PoverTy in AMrerica 437 (1965).

77 See, e.g., Brubaker v. Dickson, 310 F.2d 30 (9th Cir. 1962). 
same token, the provision of food or shelter inadequate to the purpose of maintaining the minimal standards for political and social existence, given the ability to make adequate provision, would undermine the right to privacy.

\section{A. Beyond Unconstitutional Conditions}

The doctrine of unconstitutonal conditions is vital to the task of naintaining the integrity of the Constitution and the principles which it must serve. It serves to shore up constitutional riglits against the erosion which can attend government action. But it does not help in the case of govermnental inaction, the case where the government refuses to do anything.

This poses a practical problem, particularly in the welfare field, in the following way. As a practical matter, it is clear that we as a nation will not allow anyone to starve or be deprived of shelter. But even if no one will be allowed to starve, or live in the street like a stray cat, the "other America" is still a reality, and the people in the other America, though they may be hidden from view, do not necessarily enjoy privacy. As a matter of fact, we know that they do not participate in the enjoyment or use of their fundamental riglits and that the reason is simply that they are not meaningfully available to them.

Here it should be remembered that the paupers of seventeenth-century England were not allowed to starve either, or to live in the streets. But that did not mean that they were given the minimal means of privacy or dignified existence. In the same way, the mere fact that we will make provision for the poor, and that in the process we will refrain from committing outrages upon them such as sending them to jail, or requiring them to wear big $P$ 's for "pauper" emblazoned on their clothes (as used to be required in the state of Pennsylvania) $;^{78}$ or raiding their homes at night, or forcing them to adopt or relinquish any religious or political beliefs (though we have attempted the latter in the form of loyalty oaths as a condition of housing ${ }^{79}$ and are attempting it even now in other connec-

78 "The need for or the actual receipt of assistance created . . . a veritable 'pauper statis." Thus the pauper was required to wear a badge with the letter $P$, a practice which was first given statutory sanction by the Pennsylvania Poor Law Amendment Act of 1718, $3 \mathrm{~Pa}$. Stat. at I. 1712-1724, 221 (1896); he was required to be farmed out to the bidder at public auction, see, e.g., Indiana Poor Law of 1807 . . ; ; he could be thrown into the poor-house against his will, see, e.g., Harrison v. Gilbert, 71 Conn. 724, 43 Atl. 190 (1899) (denying a writ of habeas corpus); he could and apparently still can, without violation of the constitutional guarantees, be forcibly removed to his place of settlement; Lovell v. Seeback, 45 Minn. 465,48 N.W. 23 (1891); he lost the right to vote and still does under the constitution of Massachusetts, Mass. Const. Art. of Amendments III, and Texas, Tex. Const. Art. VI, Sec. 1." RIEsenfeid \& Maxweli, Modern Social Legisiation 709 (1950).

78 The courts of three states rejected the notion of conditioning public housing on loyalty tests. Housing Authority v. Cordova, 130 Cal. App. 2d 883, 279 P.2d 215 (Super. 
tions ${ }^{80}$ )-all this does not mean that we shall be furnishing the essentials of the right to privacy or other fundamental rights.

If we are to provide those essentials necessary to the meaningful exercise of the right to privacy, we shall have to establish minimal criteria of privacy in order to meet the practical problem posed not by the refusal to furnish any assistance at all, and not by the imposition of outrageous unconstitutional conditions of high visibility such as mass midnight raids, nor even by the more subtle though not less virulent unconstitutional invasion of privacy which the means tests approach involves, but by the meagreness of the grant, the insufficiency of the funds, and the inadequacy of the housing provided.

The estabhishment of such criteria is not an insuperably difficult task; the President's Council of Economic Advisers, the Heller Committee, and others are constantly working on such questions.

The difficult task is making it clear and winning acceptance for the proposition that decent minimal standards are constitutionally required because the freedom of the individual is as much threatened by the failure to meet them as it is when the criminal courts fail to provide counsel and other minimal prerequisites of due process. And it must be made clear that poverty is not a constitutionally acceptable reason for deprivation of freedom in either case. Freedon of this sort is not for sale.

Yet, as we have noted, a root problem which must be dealt with is the persistence of the habit of thought that views access to the basic necessities of life by those who lack them not as a matter of right, of entitlement, but as a matter of charity. On this approach, it is not a matter of constitutional concern if the basic necessities are not available to all even if the power to make them available is unquestioned. The provision of some or all of such necessaries is seen as a matter of legislative discretion, and the implication, therefore, is that if the legislature should choose not to provide any welfare benefits it would be as constitutionally free as if it chose to provide them.

In order to appreciate the depth to which this gnarled root reaches in the psychology of the nation, it may be useful to recall that it was only yesterday, figuratively speaking, that the Supreme Court held that the Constitution even permitted legislative protection of the poor and dependent against the ravages of unrestrained economic power.

Not until 1936, for example, did the Supreme Court agree that the rights of employers could constitutionally be limited by legislatures

Ct. 1955); Chicago Housing Authority v. Blackman, 4 IIl. 2d 319, 122 NE.2d 522 (1954);

Lawson v. Housing Authority, 270 Wis. 269, 70 N.W.2d 605 (1955).

80 The Economic Opportunity Act, 78 Stat. 533 (1964), 42 U.S.C. \& 2966 (1964), as amended, 42 U.S.C. $\S 2966$ (Supp. I, 1965), includes a loyalty oath requirement. 
desirous of protecting the worker even if only to provide for minimum wages. In the midst of the most cataclysmic economic crisis the nation had ever known, only the barest majority of the Court could be mustered to agree that there was no equality of power between sweat shop employers and workers who were defenseless against a denial of a minimally decent wage, and that minimum wage legislation was therefore not a violation of freedom of contract and a denial of due process. "What these workers lose in wages," the Chief Justice angrily remarked, "the taxpayers are called upon to pay. The bare cost of living must be inet .... The community is not bound to provide what is in effect a subsidy for unconscionable employers. $"{ }^{\prime 81}$ Indeed, the validity of the Social Security Act was attacked in the Supreme Court the following year, partly on the ground that the law was class legislation and not in the interest of the general welfare. This time, Justice Cardozo, again for the narrowest majority, found it necessary to point out some facts of life which one would have thought were so immense and insistent as not to be avoidable:

During the years 1929 to 1936 , when the country was passing through a cyclical depression, the number of the unemployed mounted to unprecedented heights. Often the average was more than ten million; at times a peak was attained of 16 million or more. Disaster to the breadwinner meant disaster to dependents. Accordingly the roll of the unemployed, itself formidable enough, was only a partial role of the destitute or needy. The fact developed quickly that the states were unable to give the requisite relief. The problem had become national in area and dimension. There was need of help from the nation if the people were not to starve. ${ }^{82}$

But even in the face of such unprecedented catastrophe men pressed the argument that the nation could not constitutionally provide unemployment insurance. To this Justice Cardozo impatiently responded: "It is too late today for the argument to be heard with tolerance that in a crisis so extreme the use of the moneys of the nation to relieve the unemployed and their dependents is a use for any purpose narrower than the promotion of the general welfare."183

Thus, reluctantly, under the most relentless and implacable pressure, was the constitutionality of the state's discretion to enact welfare measures finally acceded to by the Supreme Court. Some of the welfare measures seemed to have the character of insurance or property rights; others were nore like simple charity. Some commentators have urged, in their desire to protect the poor person's access to benefits, that they should all be viewed as property rights. That would, of course, be an improve-

\footnotetext{
81 West Coast Hotel v. Parrish, 300 U.S. 379, 399 (1936).

82 Steward Machine Co. v. Davis, 301 U.S. 548, 586 (1937).

83 Id. at $586-87$.
} 
ment. But legislative discretion to confer benefits is also of course discretion to terminate them. Even if they are viewed not as gratuitous privileges, but as property rights bestowed by statute, future welfare benefits may be rescinded with the statute that bestows them. To be sure, the procedural protection available in the latter case is somewhat more substantial than in the former, while the benefits are provided; but one must question the assumption that equates the protections against deprivation of property with those against deprivations of fundamental human rights.

Fundamental human rights, it must be understood, are not mere property rights-though, to be sure, economic support is a partial condition of their existence. Yet, we commonly view access to the bare necessities of existence not as a matter of constitutional entitlement, even on the level of property rights. It is merely a matter of discretion, largesse, or charity.

\section{B. Property Rights versus Human Rights}

If the right to privacy is a fundamental human right, it is not a lesser right than the right to counsel. Gideon was not provided with a lawyer because there were "good-hearted people" willing to "help" him. He did not say, "Please, out of the depths of your generosity may I have the privilege of the assistance of counsel?" His position before the state was not that of a suppliant; it was that of a sovereign, a citizen. He said, "I cannot be tried unless counsel is provided because the Constitution forbids it." He did not acquire that right or lose it with any personal acquisition or loss of funds. Though there is an economically measurable cost attached to the right Gideon claimed, that right is not for sale. It costs money to have judges, but it does not follow that judgments can be purchased. Gideon's right stemmed from his status as a human being in a society where sovereignty is in the people; it had nothing to do with the status of his purse; it had everything to do with the constitutional scheme of our society. That scheme locates the fundamental rights in the people-not the rich or the employed, but the people. Those rights do not depend upon the good will of anyone, of any class, or of any government. The only power which government possesses with regard to them is the power to protect them. Indeed, im that regard, government not only is empowered to do so, it is under the most basic obligation to do so, for that is why governments, according to the political philosophy underlying our Constitution and expressed in the Declaration of Independence, are instituted. These reasons have nothing to do with mere property rights. It is not true that civil hberty depends on property rights. ${ }^{84}$ If it were, we should have to explain why the Constitution protects property only to the extent that

84 But see Reich, The New Property, 73 Yaxe L.J. 733, 771 (1964): "Indeed, in the final analysis the Bill of Rights depends upon the existence of private property." 
a rational basis for dealing with it is required of a legislature, thus satisfying due process, ${ }^{85}$ wliereas the Constitution protects fundamental liuman riglits far more stringently. ${ }^{86}$ The answer, surely, must be close to the fact that the forms in whicl property is held could alter drastically without threatening our constitutional structure, but the constitutional structure itself obviously could not be so dealt with. As Justice Holnes once put it, the Constitution did not enact Mr. Herbert Spencer's social statics or any other specific economic doctrine. ${ }^{87}$ The essence of the Constitution is the political doctrine which it embodies. Free speech, privacy, freedom from self-incrimination-these are simply not to be experimented with (as property, however, may be) on rational grounds without first amending the Constitution. And legislatures do not possess that authority. The fact that men must eat if they are to have the strength to speak is therefore an important clue as to the distinction between "property" and "fundamental riglits." That which is essential to the exercise of fundamental rights must be treated as part of them. That which is not essential to their exercise must not be treated as if it were. A mimimum income therefore cannot rightly be viewed as "property" and property should not be confused with civil liberty.

Thus, in the realm of fundamental rights-at least in the area of the fundamental right to counsel-it is clear that the notion of charity is out of place; that the notion of such rights as a function of or dependent upon property or economic power is alien; that the philosopliy expressed in the phrase "who pays the piper calls the tune" is excluded. Moreover, it is also clear that refusal to provide counsel to indigent defendants could not be justified in any of the ways that courts justify the cancellation or revocation of a property riglit. A "rational basis" would not justify such a legislative decision. If it could be justified at all, it would be possible to do so only on grounds of grave national emergency rendering the government imcapable of maintaining the courts. ${ }^{88} \mathrm{It}$ is, however, difficult to believe that even such circumstances could justify such discrimination agaimst the poor any more than it would justify such discrimination against a particular racial or religious group.

85 Cf. Ex Parte Miligan, 71 U.S. (4 Wall.) 2 (1886).

86 "[T] $]$ he existence of facts supporting the legislative judgment is to be presumed, for regulatory legislation affecting ordinary commercial transactions is not to be pronounced unconstitutional unless in the light of the facts made known or generally assumed it is of such a character as to preclude the assumption that it rests upon some rational basis within the knowledge and experience of the legislators." United States v. Carolene Prods. Co., 304 U.S. 144, 152 (1939).

87 See Lochner v. New York, 198 U.S. 45, 75 (1905) (dissenting opinion).

88 "[O]nly the gravest abuses, endangering paramount interests, give occasion for permissible limitation." Thomas v. Collins, 323 U.S. 516, 530 (1945). 
The fact, however, is that we treat those of our citizens for whom the costs of necessaries must be met out of public rather than private funds as though they are second-class citizens. But if fundamental constitutional rights are not for sale where is the authority for issuing second-class rights to be found? The answer is that there is no such authority; that the reason for the practice is to be found in incorrect, outmoded, and muddled attitudes that do not square with constitutional assumptions. Constitutionally, people must be provided with the essentials for behaving as sovereign citizens. If that means a minimum income for all who need it, minimum education, housing-so be it. ${ }^{80}$

Of course there will be those who will throw up the straw man of "socialism" or "paternalism"; but such arguments are specious. Constitutionally, they are irrelevant; politically, they are misconceived. Even Friedrich Hayek, certainly no advocate of "socialism," has argued that "there is no reason why in a society which has reached the general level of wealth which ours has attained,... . security [the certainty of a given minimum of sustenance for all] should not be guaranteed to all without endangering general freedom." Mo Moreover, it is not a question of "endangering" freedom; rather, it is a question of realizing it. Furnishing counsel to an indigent defendant is not a danger to freedon; it is a protection and a condition of it. Providing all persons with the minimal prerequisites of privacy is a guarantee and a condition of and not a threat to freedoni.

On the contrary, the threat to freedom comes rather from those who consider the recipients of welfare to be less than full citizens and persons, even if not quite criminals, and therefore fair game for treatment they would consider unconstitutional if applied to persons of means. For it is

80 The California Supreme Court in Manjares v. Newton, 64 AC 378, 411 P.2d 901, 49 Cal. Rptr. 805 (1966), held that there was an affirmative duty to provide transportation to students.

00 HAXEK, THE RoAD To SERfDOM 120 (1944); cf. Milton Friedman's suggestion of the "Negative Income Tax," which would bring all incomes up to some socially acceptable minimum. Robert Heilbroner has recently commented on such suggestions, "Indeed, I think such a plan is the most effective next step we can take in alleviating the misery of many impoverished persons, and I am happy to note its inclusion in the recent report of the President's Commission on Automation .... But alleviating poverty is one thing, and shoring up all incomes close to the line of present earmings is another. A world in which labor (including middle-class labor) no longer felt the lash of necessity would no doubt be a better world, but it would not be a world that the market system could control." Heilbroner, The Controversy over Automation, The New York Review, March 17, 1966, pp. 12, 15. Compare Article 25 (1) of the Universal Declaration of Human Rights: "Everyone has the right to a standard of living adequate for the health and well-being of bimself and of his family, including food, clothing, housing and medical care and necessary social services, and the right to security in the event of unemployment, sickness, disability, widowhood, old age or other lack of livelihood in circumstances beyond his control." 
such attitudes, the attitude which confuses property with human rights, which considers wealth not merely a mark of fortune but of moral and pohtical superiority, which envisions the provision of necessaries as charity, which sees poverty as a function of personal fault, which seeks to coerce conformity under the banner of "rehabilitation"-attitudes which in short are self-righteously or even neghigently consistent with the willingness to intrude upon and manage the lives of others, these are the real threat to freedom. It is the right to invade privacy which such attitudes nurture, and the very greatest danger to freedom is that we shall become insensitive to the outrage in proportion to its increasing practice.

Privacy is the protection of the person against authority; it is the guarantee that the individual and not the state shall remain primary; that the state sliall serve the needs of the individual, not that the individual shall be a servant of the state. It is therefore the protection of the authority of the person. Respect for privacy, respect for individual integrity, requires that one respect oneself. The government agent or private person who taps wires, who plants bugs, who snoops upon the intimacy of others cannot have any respect for his own privacy, for as a matter of principle he could have no objection to others doing to him what he himself practices. He thereby demonstrates disrespect for the rights of others as well as himself. How can we avoid the conclusion that he is the most dangerous threat to constitutional freedoms? For who will defend the Constitution if its guarantees are only to be found in its parchment? The only ultimate protection of constitutional freedom is in its practice. The alarming presence and increase of attitudes and practices violative of privacy in America is what endangers freedom. This is the source of "Big Brother's" power.

The protection of the right to privacy is therefore not merely a protection of the private rights of individuals, but it is also a protection of a most fundamental aspect of the public interest. It is a protection of freedom itself. That is why no infringement of so fundamental a right can be justified on any grounds which might suffice to justify invasions of lesser riglits such as property rights. Property rights may be regulated and abridged in the public interest. Privacy, hke freedom of speech, is itself an aspect of the public interest.

Civil liberty is indivisible; there cannot be one law for the poor and another for the rich; there cannot be one freedom for the whites and another for the blacks; there camıot be one standard of privacy for the righteous, or the loyal, or the good, and another for the wicked, the disloyal, and the bad. Civil hberty is not for sale and it is not a matter of charity. No man and no government has the discretion to divide it, dole it, or withdraw it. That is the meaning of equality: not that all must be 
identical, but that all are entitled to live under and enjoy the genuine protection of equal laws; not that all shall have the same happiness, but that all shall have the same right to pursue it, each in his own way, and not as someone else determines. "Each in his own way" and "not as someone else determines" imphes, of course, that none shall through his pursuit interfere with the capacity of others to conduct theirs. That is the meaning of the indivisibility of liberty. That is the content of the guarantee of privacy. Poverty degrades people, divides tiberty, and undermines privacy. That is why poverty must be rendered a "neutral" fact. That is why poverty must be defeated. 